UDC 338.432

DOI: https://doi.org/10.32782/2415-8801/2019-6.37

Chmil Alla

Postgraduate Student at the Department of Economics, National University of Life and Environmental Sciences of Ukraine

\title{
MODELING OF THE BEEKEEPING SECTOR BY USING THE AGMEMOD MODEL FOR UKRAINE
}

The aim of this article is to highlight the main models of partial equilibrium used in agriculture economics. As the agricultural sector of Ukraine is currently in the process of reforming, in order to adapt to EU standards. There are several agrarian policy entities that require decision-making, for example, on reforming the land market, privatization of state ownership or the agricultural tax system. The process of policymaking is not easy, often interferes with certain interests expressed by various stakeholders. Considering this tool for the objective, decision-making can help speed up the decision-making process and thus increase production, trade, and investment in Ukraine's agriculture. Based on best practices for using models in the European Union, Ukraine uses the AGMEMOD model. The AGMEMOD model is developed and maintained by the AGMEMOD Partnership, which is the consortium of numerous universities and research institutes across Europe and beyond. The main group is in Germany Thünen Institute of Market Analysis) and the Netherlands (Wageningen Economic Research) and coordinates and combines the work done with AGMEMOD model. As an example, the application of the model as shown in the creation of a new sector in the AGMEMOD model for the modeling of the beekeeping industry. The sector of beekeeping is completely new to the AGMEMOD-UA block and requires certain revision, but it is very important for Ukraine. Because Ukraine is one of the biggest exporters of honey to the European Union and one of the important exporters around the world. The beekeeping industry is strategically important not only from the standpoint of export relations of Ukraine-the world but also from the point of view of food security, increasing the yield of the crop and providing fodder base for the livestock sector. Therefore, in modeling, the agrarian sector is also advisable to model and sector beekeeping. This sector will make the model completer and more holistic. Modeling according to this system should improve the interrelations between separate sectors in the block of Ukraine and help in making agropolitical decisions that will concern not only beekeeping but also the agricultural sector.

Keywords: beekeeping, partial equilibrium modeling, agricultural policy analysis, AGMEMOD, honey market, export.

\section{МОДЕЛЮВАННЯ ГАЛУЗІ БДЖІЛЬНИЦТВА З ВИКОРИСТАННЯМ МОДЕЛІ АGМЕМОD ДЛЯ УКРАЇНИ}

Чміль А.С.

Метою цієё статті с висвітлення основних елементів формування нового сектору бджсільницвва в моделі AGMEMOD. В статті також описано основні моделі часткової рівноваги, щц застосовуються для аналізу аграрного сектору та аналізу впливу аграрної політики на сільське господарство. На даний час в Украӥні відбувається активне реформування всіх галузей, та аграрного сектору зокрема, з метою адаптації до стандартів Свропейського Союзу. Таким чином, суб'єкти аграрної політики, які впливають на прийняття рішень, наприклад, щцодо реформування земельного ринку, приватизації держсавної власності або податкової системи сільського господарства потребують зважсени аналітичних розрахунків та прогнозів щңодо можсливих наслідків впливу агрополітичних рішень на аграрний сектор. Виходячи з найкращих практик використання моделей часткової рівноваги для оцінки впливу на аграрний сектор в Свропейському Союзі, Украйна почала використовувати модель AGMEMOD. Модель AGMEMOD (https://agmemod.eu/) с економетричною, динамічною, мультинаціональною, 
мультипродуктною моделлю часткової рівноваги для аналізу аграрного ринку та політики. Роботу AGMEMOD підтримує ключова група, яка складається із співробітників Тюнен-інституту в Німеччині (Johann Hеinrich von Thünen Insitute of Market Analysis, https://www.thuenen.de/en/) ma Wageningen University \& Research (Wageningen Economic Research Institute https://www.wur.nl/en.htm). Активні користувачі моделі входять до так званого консорціуму AGMEMOD, який виконує роль наглядового органу та щорічно визначає основні напрямки розвитку моделі. Як приклад застосування моделі було показано створення нового сектору бджільництва в АGMЕМОD. Даний сектор с абсолютно новим для блоку AGMEMOD-UA і потребує певних доопрацювань, але він с дуже ваэсливим для Украӥни. Тому що Украӥна є одним з найбільших експортерів меду до Свропейського Союзу. Галузь бджільнцтва є стратегічно ваэнливою не тільки з погляду експортних відносин Украӥна - Світ, але й з точки зору продовольчої безпеки, підвищення урожайності сектору рослинництва та забезпечення кормовою базою сектор тваринництва. Тому, при моделюванні аграрного сектору доцільно такожс моделювати і сектор бджільництва. Саме цей сектор зробить модель більш повною та цілісною. Моделювання за цією системою має покращити взаємозвязки міз окремими секторами в блоці Україна та допомогти в прийнятті агрополітичних рішень ццо будуть стосуватися не тільки бджільництва, а й аграрного сектору в цілому.

Ключові слова: бджільництво, моделювання часткової рівноваги, аналіз сільськогосподарської політики, AGMEMOD, ринок меду, експорт.

\section{МОДЕЛИРОВАНИЕ СЕКТОРА ПЧЕЛОВОДСТВА С ИСПОЛЬЗОВАНИЕМ МОДЕЛИ АGМЕМОD ДЛЯ УКРАИНЫ}

Чмиль А.С.

Целью данной статьи является выделение основных моделей частичного равновесия, используемых в экономике сельского хозяйства. Поскольку аграрный сектор Украины в настоящее время находится в процессе реформирования для того, чтобы адаптироваться к стандартам ЕС. Процесс внедрения новой политики является не легким, часто мешает определенным интересам, выраженным различными заинтересованными сторонами. В свете этого инструмента для объективного принятия решений может помочь ускорить процесс принятия речений и тем самым увеличить производство, торговлю и инвестиции в сельское хозяйство Украины. Основываясь на передовой практике использования моделей в Европейском Союзе, Украина использует модель AGMEMOD. В качестве примера применения.модели было показано создание нового сектора в модели АGMEMOD для моделирования пчеловодства. Сектор пчеловодства совершенно новый для блока AGMEMOD-UA и требует определенной доработки, но это очень важно для Украины. Потому что Украина является одним из крупнейиих экспортеров меда в Европейский Союз и одним из важных экспортеров во всем мире. Пчеловодство имеет стратегическое значение не только с точки зрения экспортных отночений Украины-мира, но и с точки зрения продовольственной безопасности, повышения урожайности и обеспечения кормовой базы для жниотноводческого сектора. Поэтому при моделировании аграрного сектора такэе целесообразно моделировать и сектор пчеловодства. Этот сектор сделает модель более полной и целостной. Моделирование по этой системе долюсно улучшить взаимоотношения между отдельными секторами блока Украины и помочь в принятии агрополитических решений, которые будут касаться не только пчеловодства, но и аграрного сектора в целом.

Ключевые слова: пчеловодство, моделирование частичного равновесия, анализ аграрной политики, AGMEMOD, рынок меда, экспорт.

Problem statement. The agrarian policy is an important component of state economic regulation, because, subject to the promotion of effective political measures, it is able to create conditions and promote the development of agrarian economy, provide food security, support the development of Related to agriculture, industries and contribute to the development of rural areas. Taking into consideration that every political decision provokes different consequences, it is important to predict them, evaluate and timely correct these measures in order to implement the most effective for society and the country of decisions. The question of the formation of methods of estimation of accepted or projected political decisions is highlighted not in full measure, because, analyzing agrarian policy and agrarian Science in Ukraine, it is possible to conclude about insufficient use of the economic apparatus The main model of partial equilibrium of the European Union is analyzed in the article.

Analysis of resents research and publications. Research problems of analyzing and simulating the functioning of the agrarian sector are dedicated to the work of many scientists such as M. Bogonos, M. Banse, P. Salamon [3], O. Von Ledebur, M. Van Leeuwen,
F. Bouma, G. Salputra [7], T. Fellmann, O. Nekhay. In particular, the agricultural sector investigated Ukrainian scientists A. Dibrova, S. Kvasha, V. Onegina and others.

Selection of previously unsolved parts of the common problem. The studies on the agricultural sector modeling demonstrate insufficient use of partial equilibrium models to assess the impact of agropolytical solutions and to simulate the activities of the agrarian sector. Therefore, on the example of the use of AGMEMOD is the econometric dynamic partial equilibrium model, which analyzes the impact of scenarios of political decisions on the agricultural sector of the EU countries, as well as Ukraine has shown the main aspects of creating a new sector for the Ukrainian beekeeping industry.

The formulation of the aims of the article (problem statement) is to explain the basic elements of creating a new sector for the beekeeping industry in the AGMEMOD model. And, also to describe the most popular partial equilibrium models used to analyze the agrarian sector and analyze the impact of agrarian policy on agriculture.

Statement of the basic material. The agriculture sector of Ukraine is currently in the reform process, with 
the objective to adapt to EU standards. There are several agricultural policy subjects requiring policy decision making, e.g. regarding the reform of the land market, privatization of state property or the agriculture tax system. The policymaking process is not easy, frequently hampered by interests expressed by different stakeholders. Considering this, tools for objective decision making could help speeding up policy decision-making processes and thus boosting production, trade, and investments in the agriculture sector of Ukraine.

Partial equilibrium models' main characteristic is that they concentrate on the isolated market, considering the rest of the economy as an unchanging background for the analysis of supply and demand in this market. When compared to general equilibrium models, PE models are more limited in the sense that they cannot include the effects of dispersion of changes in the analyzed market to other sectors of the economy. However, they can be quite useful for a detailed examination of many factors affecting the behavior of agents in this market, especially when the influence of these factors does not seriously affect sectors other than the one in question. Thanks to their detailed structure, they often include diversified policy variables and services to study the effects of their changes [2].

In addition, the models are classified according to the major links (such as farm-region or sector-economy) which they emphasize, the techniques and methods which they use, and the ways in which technological alternatives and migration activities are incorporated into them. Traditionally, these models are grouped into computable general equilibrium (CGE) and partial equilibrium models.

Econometrics is often used for the estimation of policy effects in agriculture. There are two main approaches in this respect. The first is the estimation of the influence of policy variables within a single equation econometric model. And the second is the estimation within a simultaneous equations system of behavioral relationships. In such a system, supply, demand and price are endogenous variables, and the model is closed when supply equals demand. The equations may be broken into several equations depending on the system modeled. For example, if a commodity is exported, its total demand is a sum of domestic and export demands that depend on different sets of variables. Simulation models include partial and general equilibrium approaches. ESIM and WATSIM [3] are examples of partial equilibrium models. They simulate future effects of the policy reforms on production, consumption, trade and domestic prices of a wide range of agricultural products of the EU countries in static perspective26. Changes in the rest of the sectors of the economy are considered only exogenously. Parameters of the functions of these models are calibrated to the values of the models' reference year. GTAP is an example of a computable general equilibrium model. It is characterized by global coverage and simulates the development of all the sectors of economies of the countries considered. The model also includes linkages and feedbacks between the sectors and simulates bilateral trade flows between the countries. AGMEMOD [3] and CAPRI [4] are partial equilibrium models that incorporate several modeling techniques. AGMEMOD estimates future effects of the policy reforms on the agricultural sector of the EU and few non-EU countries on a year-to-year basis (i.e., dynamic perspective). Unlike AGMEMOD, CAPRI is a static model and includes only EU countries. The main difference between the two modeling systems is that in AGMEMOD, parameters of the core functions (e.g., areas of crops harvested, yields, animal stocks, consumption) are estimated econometrically, and in CAPRI, mathematical programming technique is used for estimation of the decision-making change.

The commodity coverage of the current version of the model extends to markets for grains, oilseeds and to the markets for their associated meals and oils, root crops, livestock milk and dairy products, apples, oranges, tobacco, and cotton. Most of the equations in the model have been estimated using annual data over the period 1973-2018, or over shorter periods in case of data were not available (such as for the new member states).

Ukraine is divided into 6 regions according to the parties of the world in AGMEMOD.

The previous Ukrainian model in AGMEMOD is developed by Van Leeuwen et all[3]. This version uses historical data until 2010 and starts projections in 2011. Since 2012 Ukraine's country block has been included in the model [3]. In the new version, historical data till 2013 is used and projection starts in 2014. Additionally, a new feature in AGMEMOD has introduced: the regionalization of a country. Ukraine is the first country to be regionalized in AGMEMOD. After consultation with our Ukrainian partners, six regions of Ukraine are defined, as shown in Table 1.

The variables entering in each sub-model represent consecutive positions in the balance sheet of each market. On the supply side the beginning stocks, production, and imports are being considered and on the demand side the domestic use, exports and ending stock are modeled. For each product in each country also the respective domestic prices (market-clearing prices) are modeled. The equilibrium in each market is reached in the model also on the level of the whole EU.

This implies that the EU net export variable is used as the closing variable at the EU level. The necessary condition for the model to be solved is that the equality between supply and demand in each market in each country must hold [5].

The model contains endogenous and exogenous variables (parameters). The endogenous variables are mostly prices and the variables determining the supply and

Table 1. Regionalization of Ukraine in AGMEMOD model

\begin{tabular}{|c|c|c|c|c|c|c|}
\hline Regions & $\begin{array}{c}\text { West } \\
\text { (L'viv, Karpaty, } \\
\text { Ivano-Frankivsk, } \\
\text { Chernivtsi, } \\
\text { Ternopol) }\end{array}$ & $\begin{array}{c}\text { Center } \\
\text { (Poltava, Kirovograd, } \\
\text { Vinnitsa, Cherkasy, } \\
\text { Khmelnitsky, } \\
\text { Dnipropetrovsk) }\end{array}$ & $\begin{array}{c}\text { East } \\
\text { (Donetsk, } \\
\text { Lugansk, } \\
\text { Kharkov) }\end{array}$ & $\begin{array}{c}\text { South } \\
\text { (Zaporizhian, } \\
\text { Mykolaiv, } \\
\text { Odesa, Kherson) }\end{array}$ & Crimea & $\begin{array}{c}\text { North } \\
\text { (Volyn, } \\
\text { Zhytomyr, Kyiv, } \\
\text { Rivne, Sumy, } \\
\text { Chernihiv) }\end{array}$ \\
\hline $\begin{array}{l}\text { Mnemonics in } \\
\text { AGMEMOD }\end{array}$ & UA_WE & UA_CE & UA_EA & UA_SO & UA_CR & UA_NO \\
\hline
\end{tabular}

Source: developed by the author based on [7] 
demand in the market of each product in every country. The exogenous variables include a set of variables describing the general macroeconomic conditions for the functioning of the agricultural market (GDP, inflation, exchange rates, population), world agricultural prices as well as CAP instruments. A change in exogenous variables may determine the assumptions of scenarios simulated by the model.

In the AGMEMOD model, the equilibrium is reached in each market of each country independently. The characteristic feature of the model is that the price does not serve as a variable, which would lead to the equality between the supply and demand in the separate market at a given moment of time, but is exogenous for the supply and demand variables at a given moment of time. Therefore, one of the positions of the trade balance sheet, in most cases imports or exports, is treated as a closing variable. On the country level, however, there exist interdependencies between markets of products. They result from the assumptions of substitution or complementarities between the products. The arable land allocation between different kinds of crops according to the relative profitability of their products can be given as an example of substitution. At the same time, the use of different grains, oilseeds, and the derived products as fodder in livestock production determines the relation of complementarity between crops and livestock. As it was mentioned before, country market models are solved independently, nevertheless, the behavior of supply and demand variables in each member state market model is driven by a common factor, so-called key price of this product. For each market included in the AGMEMOD model, the key price is the price of the product in the country, which is its most important producer in the EU. In most cases, the country's price of a given commodity depends on the simultaneous development of key prices, lagged domestic and EU (or key country) selfsufficiency rates and other variables [5].

The behavioral equations of the model are mostly individually estimated with econometric techniques (generalized least squares). However, in situations where too short time series were accessible, the quality of data was unsatisfactory, important structural breaks (e.g. policy regime change) were observed or the estimation resulted in the values of parameters inconsistent with the economic theory (such as positive price elasticity of demand or negative reaction of domestic price to the key price), calibration techniques were used.

Considering many countries and commodities included in the AGMEMOD model, the number of parameters and equations to be estimated is very large. A decentralized estimation strategy is employed to make the task manageable and better informed: all equations of a country model are estimated by the AGMEMOD partner responsible for that country. It is thus impossible to report in detail all the estimation procedures that have been followed as well as all estimation results. Rather we summarize the general criteria provided to each AGMEMOD national team undertaking the processes of estimating the parameters of their country model. Country level econometric estimation results, detailed specification test information and complete documentation of the AGMEMOD country models can be requested, country-by-country, directly from the respective national teams. The general criteria break the model parameterization process into a maximum of five stages: pre-estimation, estimation, post-estimation, calibration, and validation.

Conclusions and results of this study are a highlight of the main elements of forming a new beekeeping sector in the AGMEMOD model. The article also describes the main models of partial equilibrium used for the analysis of the agrarian sector and analysis of the influence of agrarian policy on agriculture.

We also added three new variables HN-honey natural, HP-honey bee colonies productiveness and HC-Honey bee colonies for implementation of the honey market. This sector is broken down only by region. Honey producers in Ukraine are divided into 2 types: households and public enterprises. Regarding the geography of production, it is advisable to distinguish the following regions: West (L'viv, Karpaty region, Ivano-Frankivsk, Chernivtsi, Ternopil), Center (Poltava, Kirovograd, Vinnytsia, Cherkasy, Khmelnytskyi, Dnipropetrovsk), East (Donetsk, Lugansk, Kharkiv), South (Zaporizhia, Mykolaiv, Odesa, Kherson), Crimea, North (Volyn, Zhytomyr, Kyiv, Rivne, Sumy, Chernihiv).

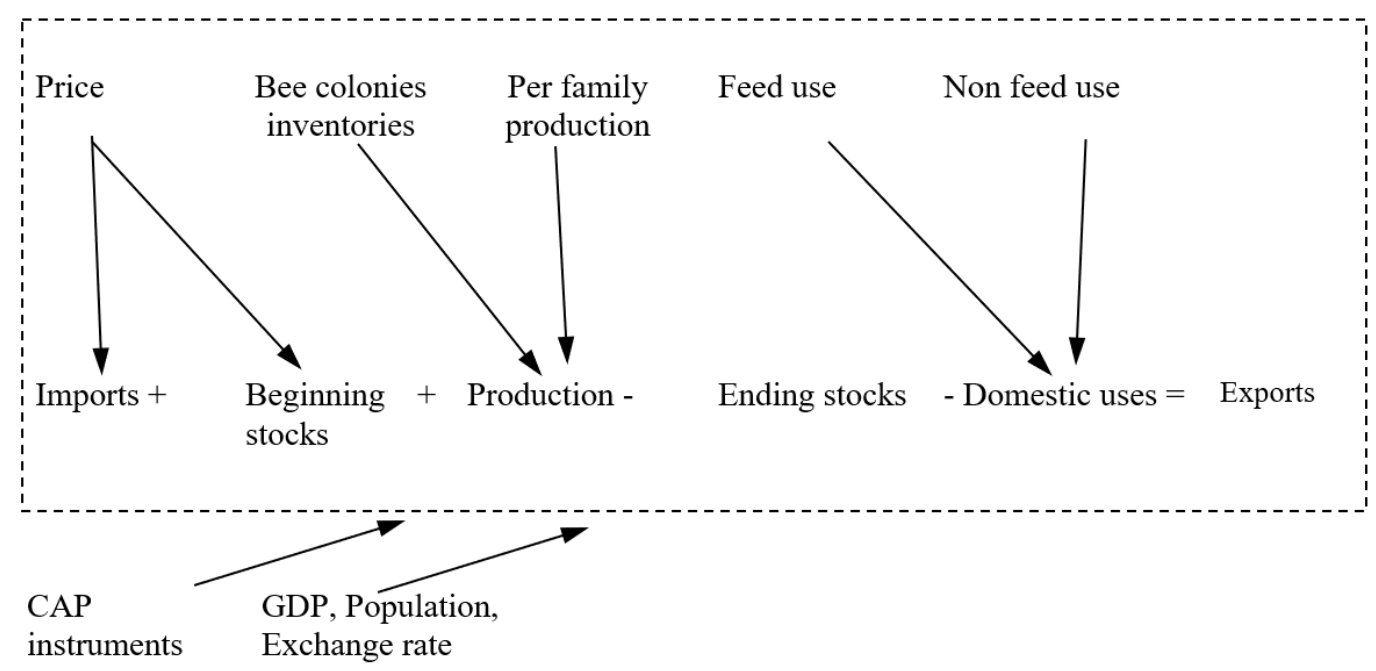

Figure 1. Beekeeping sector modeling structure

Source: developed by the author 
The model contains a system of equations that are unlocked simultaneously. This model also considers the influence of exogenous factors, including World market price, GDP, exchange rate and other indicators that compute AGMEMOD. For example, the price of honey depends on the World market price; The exchange rate allows you to convert world prices into national currency, which is necessary for the assessment of domestic market prices. The GDP deflator allows you to calculate real market prices, and the population influences the overall level of consumption in the country. Real GDP shows the level of consumer profits. Thus, due to the consideration of exogenous parameters, we obtain more accurate endogenous variables. To endogenous variables, we include such data as Honey production, Honey imports, Honey exports, Honey domestic use, Honey ending stocks,
Honey per family production, Honey food use and others. To solve this system, a large amount of historical data is required. Figure 1 shows a beekeeping sector modeling structure.

Data sources for the honey production are mainly compiled from two sources: The Food and Agriculture Organization of the United Nations and the State Statistics Service of Ukraine.

In AGMEMOD, each indicator of the honey sector is described by the corresponding equation. These equations are estimated using the program "R-Studio" and time series regression and formed in the system. In the end, we will get detailed simulation results that include predictive estimates of supply, demand, import, the export of domestic prices, etc. Based on the above, we can predict the export potential of honey and the development of the beekeeping industry.

1. AGMEMOD (2018) Agri-Food projections AGMEMOD for the EU Member States. URL: https://agmemod.eu/ (accessed: 27 February 2018).

2. APD (2017) Agricultural Outlook Ukraine 2017-2030. Baseline: projection of the development of the agricultural sector in current economic and political frameworks and absent monetary state support. Kyiv.

3. Banse, M., P. Salamon, O. Von Ledebur, M. Van Leeuwen, F. Bouma, G. Salputra, T. Fellmann, O. Nekhay (2012) Impact of Russia and Ukraine on the international price formation and the EU markets - A Model based analysis, paper prepared for the 123rd EAAE Seminar 'Price Volatility and Farm Income Stabilisation' held in Dublin, 23.-24.02.12.

4. Britz, W. and P. Witzke (2011) CAPRI model documentation 2011. The University of Bonn.

5. Mariusz Hamulczuk, Katarzyna Hertel (2009) AGMEMOD model - Structure and application for analysis and simulation of the Polish agriculture sector. METODY ILOŚCIOWE W BADANIACH EKONOMICZNYCH X, 2009 , str. 88-98.

6. SSSU (2017) Agriculture of Ukraine, Statistical yearbook, State Statistics Service of Ukraine. URL: http://www.ukrstat.gov.ua (accessed: 13.09.2018).

7. Verena Wolf, Guna Salputra (2015) Deliverable 5.3: Extension of AGMEMOD. Submission date: 31.08.2015. Thünen Institute of Market Analysis, Germany. JRC Institute for Prospective Technological Studies, Spain.

E-mail: alla.chmil@ukr.net 